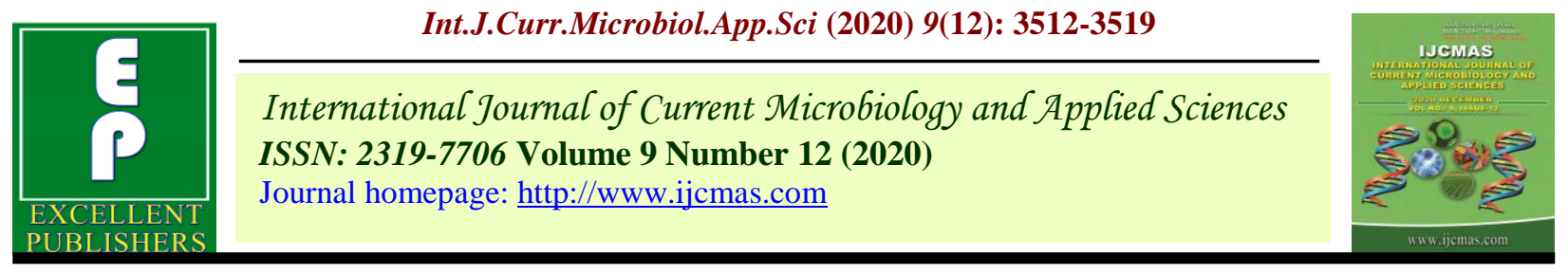

Original Research Article

https://doi.org/10.20546/ijcmas.2020.912.417

\title{
Effect of Zinc and Boron on Uptake, Yield and Quality of Linseed (Linum usitatissimum L.)
}

\author{
Md. Parwaiz Alam, Kumari Menka*, Sulochna, Md. Naiyar. Ali and R. K. Lakra
}

Department of Agronomy, Birsa Agricultural University, Ranchi-834006, Jharkhand, India

*Corresponding author

\section{A B S T R A C T}

\section{Keywords}

Linseed, zinc, boron, yield, oil yield, uptake and quality

\section{Article Info}

Accepted:

25 November 2020

Available Online:

10 December 2020
An experiment was conducted during Rabi 2018-19 and 2019-20 at Research Farm of Birsa Agricultural University, Kanke, Ranchi, Jharkhand to study "The effect of Zinc and Boron on uptake, yield and quality of linseed (Linum usitatissimum L.)". The experiment was laid out in randomized block design with three replications. The treatments comprised soil application of Zn @ $5 \mathrm{~kg} / \mathrm{ha}$, foliar application of $\mathrm{ZnSO}_{4} @ 0.5 \%$ at $45 \mathrm{DAS}$, soil application of $\mathrm{Zn} @ 5 \mathrm{~kg} / \mathrm{ha}+$ foliar application of $\mathrm{ZnSO}_{4} @ 0.5 \%$ at $45 \mathrm{DAS}$, soil application of B @ $1.5 \mathrm{~kg} / \mathrm{ha}$, foliar application of Borax @ 0.3\% at 45 DAS, soil application of B @ $1.5 \mathrm{~kg} / \mathrm{ha}$ + foliar application of Borax @ $0.3 \%$ at 45 DAS, foliar application of $\mathrm{ZnSO}_{4} @$ $0.5 \%$ + foliar application of Borax @ $0.3 \%$ at 45 DAS, soil application of Zn @ 5 $\mathrm{kg} / \mathrm{ha}+$ soil application of B @ $1.5 \mathrm{~kg} / \mathrm{ha}$ compared with control along with RDF (40:20:20 kg NPK/ha) common to all treatments. Foliar application of $\mathrm{ZnSO}_{4} @$ $0.5 \%$ + foliar application of borax @ $0.3 \%$ at 45 DAS was found superior in terms of seed yield, straw yield, oil content, oil yield, zinc and boron concentration in seed and straw, zinc and boron concentration in soil after harvest and zinc and boron uptake by seed and straw in both years of experimentation.

\section{Introduction}

Linseed (Linum usitatissimum L.) is a major rabi oilseed crop of the country and it is next in importance to rapeseed and Mustard in area as well as production. India occupies fourth largest linseed growing country in the world $(10.8 \%)$ after Kazakhistan, Canada and Russia. Linseed seed rich in protein (20\%), oil $(41 \%)$ and dietary fibre $(28 \%)$. Linseed is basically an industrial oilseed crop and its each and every part is endowed with commercial and medicinal importance (Marchenkov et al., 2003). It is grown mainly for seeds which are used for extracting oil as well as fibre which is used for manufacturing of linen. The seed of linseed contains about 33-47 percent oil. It contains 35-70\% linolenic acid (Omega-3 fatty acid), the factor which reduces blood cholesterol concentration. At 
present linseed is cultivated in about 326.01 thousand ha contributing 173.62 thousand tonnes to the annual oilseed production of the country with the productivity of $545 \mathrm{~kg} / \mathrm{ha}$. While in Jharkhand it is cultivated over 52.07 thousand ha with production of 29.68 thousand tonnes (P.C. Report, 2018-19, AICRP on linseed). It is generally grown under rainfed condition with little use of micronutrients, such as zinc and boron, however, its cultivation is widely extended in irrigated areas because of higher yield potential. Linseed has many industrial, medicinal properties and used for value added product. One of the limiting factors for low yield is due to poor management of inputs.

The average yield of flax is very low in India due to many constraints like poor soil fertility, inadequate application of macro and micronutrients, competition with other crop and traditional crop management practices. Due to constantly increasing demand of the crop, there is a direct need to increase seed yield potential of flax crop. Its production can be increased by growing high yielding cultivators and by the uses of macro and micronutrients in balance quantity. Micronutrients especially zinc and boron play very important role in increasing yield, uptake and quality of linseed. The deficiency of these two micronutrients in soil adversely affects the growth and development of linseed. Zinc is one of the essential micronutrients require for optimum crop growth and deficiency of it causes various adverse effect on growth and yield of linseed.

Boron plays a significant role in enzyme activation, protein synthesis, improves photosynthesis and is associated with calcium uptake and its utilization. Boron application imposed a positive trend in production of more dry matter, seed yield and oil content. The research was on zinc and boron application and its effect on growth and development of linseed is very meagre. Therefore, an experiment was conducted to find out the suitable dose of zinc and boron for linseed in sole as well as combined application.

\section{Materials and Methods}

The study was conducted during two consecutive year of 2018-19 and 2019-20 in rabi season at Crop Research Farm, Eastern Section of the Birsa Agricultural University, Ranchi-834006 to evaluate "The effect of Zinc and Boron on uptake, yield and quality of linseed (Linum usitatissimum L.)". The linseed variety taken for experimentation was "Priyam". The experiment was laid out in Randomized Block Design replicated thrice with nine treatments viz., soil application of $\mathrm{Zn} @ 5 \mathrm{~kg} / \mathrm{ha}$, foliar application of $\mathrm{ZnSO}_{4} @$ $0.5 \%$ at $45 \mathrm{DAS}$, soil application of Zn@5 $\mathrm{kg} / \mathrm{ha}+$ foliar application of $\mathrm{ZnSO}_{4} @ 0.5 \%$ at 45 DAS, soil application of B @ $1.5 \mathrm{~kg} / \mathrm{ha}$, foliar application of Borax @ $0.3 \%$ at 45 DAS, soil application of B @ $1.5 \mathrm{~kg} / \mathrm{ha}+$ foliar application of Borax @ $0.3 \%$ at 45 DAS, foliar application of $\mathrm{ZnSO}_{4} @ 0.5 \%+$ foliar application of Borax @ $0.3 \%$ at 45 DAS, soil application of Zn @ $5 \mathrm{~kg} / \mathrm{ha}+$ soil application of B @ $1.5 \mathrm{~kg} / \mathrm{ha}$ with control along with RDF (40:20:20 kg NPK/ha) common to all treatments.

The soil of the experimental site was sandy loam in texture, slightly acidic in reaction (5.84), low in organic carbon $(0.41 \%)$ and available nitrogen $(175.79 \mathrm{~kg} / \mathrm{ha})$, medium in available phosphorus (21.82 $\mathrm{kg} / \mathrm{ha})$ and potassium $(186.54 \mathrm{~kg} / \mathrm{ha})$ with low in zinc $(0.68 \mathrm{mg} / \mathrm{kg})$ and boron $(0.44 \mathrm{mg} / \mathrm{kg})$. The yield, uptake and quality were recorded as per the standard procedure by sampling from three places in each plot. All data recorded were analyzed with the help of analysis of variance (ANOVA) technique (Gomez and Gomez 1984). 


\section{Results and Discussion}

\section{Seed yield and Straw yield of linseed as affected by application of $\mathrm{Zn}$ and $\mathrm{B}$}

An appraisal of data (Table 1) revealed that foliar application of $\mathrm{ZnSO}_{4} @ 0.5 \%$ + foliar application of Borax @ $0.3 \%$ at 45 DAS recorded significantly superior seed yield (12.99 $\mathrm{q} / \mathrm{ha}$ and $13.35 \mathrm{q} / \mathrm{ha}$ ) as compared to rest of the treatments except the treatment where soil application of $\mathrm{Zn} @ 5 \mathrm{~kg} / \mathrm{ha}+$ foliar application of $\mathrm{ZnSO}_{4} @ 0.5 \%$ at 45 DAS (11.82 q/ha and $12.04 \mathrm{q} / \mathrm{ha})$ and soil application of B @ $1.5 \mathrm{~kg} / \mathrm{ha}+$ foliar application of Borax @ $0.3 \%$ at 45 DAS (12.12 q/ha and $12.28 \mathrm{q} / \mathrm{ha})$ was applied. However, the data indicated that zinc and boron had significantly affected the straw yield and was recorded maximum with the treatment with foliar application of $\mathrm{ZnSO}_{4} @$ $0.5 \%$ + foliar application of Borax @ 0.3\% at 45 DAS (21.26 q/ha and $22.37 \mathrm{q} / \mathrm{ha})$ in the year 2018-19 and 2019-20 respectively. This might be because of foliar and soil application of micronutrients which effectively fulfill the nutrient requirements of the linseed crop as compared to other treatments. The results are in conformity with the findings of Singh et al., (2020), Mishra et al., (2016) and Kumar et al., (2014).

Oil content and Oil yield of linseed as affected by application of $\mathrm{Zn}$ and $\mathrm{B}$

The data on oil content (\%) and oil yield $(\mathrm{kg} / \mathrm{ha})$ is presented in Table 1 . The different treatment combination did not affect the oil content. However, the highest oil content (39.21\% and $39.86 \%$ ) was observed with the foliar application of $\mathrm{ZnSO}_{4} @ 0.5 \%+$ foliar application of Borax @ $0.3 \%$ at 45 DAS in both the years. The significant higher oil yield (509.34 kg/ha and $533.51 \mathrm{~kg} / \mathrm{ha}$ ) was obtained in the treatment where foliar application of $\mathrm{ZnSO}_{4} @ 0.5 \%$ + foliar application of Borax
@ $0.3 \%$ at 45 DAS was applied over rest of the treatment except treatment where soil application of $\mathrm{Zn} @ 5 \mathrm{~kg} / \mathrm{ha}+$ foliar application of $\mathrm{ZnSO}_{4} @ 0.5 \%$ at 45 DAS (458.50 kg/ha and $475.54 \mathrm{~kg} / \mathrm{ha})$ and soil application of B @ $1.5 \mathrm{~kg} / \mathrm{ha}+$ foliar application of Borax @ $0.3 \%$ at 45 DAS (473.29 kg/ha and $487.50 \mathrm{~kg} / \mathrm{ha}$ ) was applied in both the year of experimentation. Improvement in oil content and oil yield with zinc sulphate and borax might be due to involvement of sulphur directly in oil synthesis. The results reported by Maharnor et al., (2015) and Bhagwat et al., (2018) are in close conformity in these findings.

\section{Zinc content and its uptake by linseed as affected by application of $\mathrm{Zn}$ and $B$}

Data in Table 2 showed that zinc content in soil after harvest of the crop was found significantly higher $(1.24 \mathrm{mg} / \mathrm{kg}$ and 1.35 $\mathrm{mg} / \mathrm{kg}$ ) with the treatment where soil application of $\mathrm{Zn} @ 5 \mathrm{~kg} / \mathrm{ha}+$ foliar application of $\mathrm{ZnSO}_{4} @ 0.5 \%$ at 45 DAS was applied over rest of the treatments but at par with soil application of $\mathrm{Zn} @ 5 \mathrm{~kg} / \mathrm{ha}(1.18$ $\mathrm{mg} / \mathrm{kg}$ and $1.27 \mathrm{mg} / \mathrm{kg}$ ), foliar application of $\mathrm{ZnSO}_{4} @ 0.5 \%$ at 45 DAS $(1.16 \mathrm{mg} / \mathrm{kg}$ and $1.25 \mathrm{mg} / \mathrm{kg}$ ), foliar application of $\mathrm{ZnSO}_{4}$ @ 0.5\% + Borax@0.3\% at 45 DAS (1.09 mg/kg and $1.18 \mathrm{mg} / \mathrm{kg}$ ) and soil application of Zn @ $5 \mathrm{~kg} / \mathrm{ha}+\mathrm{B} @ 1.5 \mathrm{~kg} / \mathrm{ha}(1.12 \mathrm{mg} / \mathrm{kg}$ and 1.23 $\mathrm{mg} / \mathrm{kg}$ ) was applied in both the years of experimentation. The data on nutrient content in both seed and straw indicates that treatment with foliar application of $\mathrm{ZnSO}_{4} @ 0.5 \%+$ foliar application of Borax @ 0.3\% at 45 DAS was found significantly higher over rest of the treatments except soil application of $\mathrm{Zn}$ @ 5 $\mathrm{kg} / \mathrm{ha}$, foliar application of $\mathrm{ZnSO}_{4} @ 0.5 \%$ at 45 DAS, soil application of $\mathrm{Zn} @ 5 \mathrm{~kg} / \mathrm{ha}+$ foliar application of $\mathrm{ZnSO}_{4} @ 0.5 \%$ at 45 DAS and soil application of Zn @ $5 \mathrm{~kg} / \mathrm{ha}+\mathrm{B}$ ( $1.5 \mathrm{~kg} / \mathrm{ha}$ in both years of experimentation and lowest was found in control. 
Table.1 Yield and Oil content of linseed as affected by application of $\mathrm{Zn}$ and B

\begin{tabular}{|c|c|c|c|c|c|c|c|c|}
\hline \multirow[t]{2}{*}{ Treatments } & \multicolumn{2}{|c|}{ Seed yield $(\mathbf{q} / \mathbf{h a})$} & \multicolumn{2}{|c|}{$\begin{array}{l}\text { Straw yield } \\
(\mathbf{q} / \mathbf{h a})\end{array}$} & \multicolumn{2}{|c|}{ Oil content $(\%)$} & \multicolumn{2}{|c|}{ Oil yield (kg/ha) } \\
\hline & $\begin{array}{c}2018- \\
19\end{array}$ & $\begin{array}{c}2019- \\
20\end{array}$ & $\begin{array}{c}2018- \\
19\end{array}$ & $\begin{array}{c}2019- \\
20\end{array}$ & $\begin{array}{c}2018- \\
19\end{array}$ & $\begin{array}{c}2019- \\
20\end{array}$ & $\begin{array}{c}2018- \\
19\end{array}$ & $\begin{array}{c}2019- \\
20\end{array}$ \\
\hline$T_{1}:$ (control) & 7.92 & 8.85 & 10.91 & 12.88 & 35.36 & 36.08 & 280.05 & 319.31 \\
\hline $\mathrm{T}_{2}$ : Soil application Zn @ $5 \mathrm{~kg} / \mathrm{ha}$ & 10.15 & 10.72 & 17.54 & 19.63 & 37.17 & 37.97 & 377.28 & 407.43 \\
\hline $\begin{array}{c}\text { T3:Foliar application } \mathrm{ZnSO}_{4} @ \\
\text { 0.5\% at } 45 \mathrm{DAS}\end{array}$ & 10.43 & 10.94 & 18.87 & 20.44 & 37.64 & 38.42 & 392.59 & 419.52 \\
\hline $\begin{array}{c}\mathrm{T}_{4} \text { : Soil application } \mathrm{Zn} @ 5 \mathrm{~kg} / \mathrm{ha}+ \\
\text { Foliar application of } \mathrm{ZnSO} \mathrm{SO}_{4} @ \\
0.5 \% \text { at } 45 \mathrm{DAS}\end{array}$ & 11.82 & 12.04 & 20.73 & 21.16 & 38.79 & 39.56 & 458.50 & 475.54 \\
\hline $\mathrm{T}_{5}:$ Soil application B @ $1.5 \mathrm{~kg} / \mathrm{ha}$ & 10.74 & 11.03 & 18.28 & 19.86 & 37.95 & 38.64 & 407.58 & 424.33 \\
\hline $\begin{array}{c}\mathrm{T}_{6} \text { :Foliar application Borax @ } \\
\text { 0.3\% at } 45 \text { DAS }\end{array}$ & 11.32 & 11.55 & 17.96 & 19.21 & 38.52 & 39.32 & 436.05 & 454.24 \\
\hline $\begin{array}{c}\mathrm{T}_{7} \text { : Soil application B @ } 1.5 \mathrm{~kg} / \mathrm{ha}+ \\
\text { Foliar application Borax @ 0.3\% } \\
\text { at } 45 \text { DAS }\end{array}$ & 12.12 & 12.28 & 20.08 & 21.00 & 39.05 & 39.75 & 473.29 & 487.50 \\
\hline $\begin{array}{c}\mathrm{T}_{8} \text { : Foliar application } \mathrm{ZnSO}_{4} @ \\
0.5 \% \text { + Borax @ 0.3\% at } 45 \mathrm{DAS}\end{array}$ & 12.99 & 13.35 & 21.26 & 22.37 & 39.21 & 39.86 & 509.34 & 533.51 \\
\hline $\begin{array}{c}\text { T}_{9} \text { : Soil application Zn @ } 5 \mathrm{~kg} / \mathrm{ha}+ \\
\text { B @ } 1.5 \mathrm{~kg} / \mathrm{ha}\end{array}$ & 10.82 & 11.06 & 19.56 & 20.94 & 38.33 & 38.93 & 414.73 & 430.71 \\
\hline SEm \pm & 0.46 & 0.49 & 0.77 & 0.82 & 1.31 & 1.80 & 17.40 & 25.16 \\
\hline $\mathrm{CD}(\mathbf{P}=\mathbf{0 . 0 5})$ & 1.37 & 1.48 & 2.30 & 2.46 & NS & NS & 52.15 & 75.41 \\
\hline CV (\%) & 7.2 & 7.5 & 7.3 & 7.2 & 6.0 & 8.0 & 7.2 & 9.9 \\
\hline
\end{tabular}


Table. 2 Zinc content and its uptake by linseed as affected by application of $\mathrm{Zn}$ and B

\begin{tabular}{|c|c|c|c|c|c|c|c|c|c|c|c|c|}
\hline \multirow[t]{3}{*}{ Treatments } & \multicolumn{6}{|c|}{ Zinc content (mg/kg) } & \multicolumn{6}{|c|}{ Zinc uptake (g/ha) } \\
\hline & \multicolumn{2}{|c|}{ Soil } & \multicolumn{2}{|c|}{ Seed } & \multicolumn{2}{|c|}{ Straw } & \multicolumn{2}{|c|}{ Seed } & \multicolumn{2}{|c|}{ Straw } & \multicolumn{2}{|c|}{ Total } \\
\hline & $\begin{array}{c}2018- \\
19\end{array}$ & $\begin{array}{l}2019 \\
-20\end{array}$ & $\begin{array}{c}2018- \\
19\end{array}$ & $\begin{array}{c}2019- \\
20\end{array}$ & $\begin{array}{c}2018- \\
19\end{array}$ & $\begin{array}{c}2019- \\
20\end{array}$ & $\begin{array}{c}2018- \\
19\end{array}$ & $\begin{array}{c}2019- \\
20\end{array}$ & 2018-19 & 2019-20 & 2018-19 & $2019-20$ \\
\hline $\mathbf{T}_{1}:($ control $)$ & 0.42 & 0.51 & 32.83 & 34.45 & 41.99 & 44.85 & 26.00 & 30.18 & 45.81 & 57.68 & 71.81 & 87.85 \\
\hline $\mathrm{T}_{2}$ : Soil application Zn @ $5 \mathrm{Kg} / \mathrm{ha}$ & 1.18 & 1.27 & 38.75 & 39.60 & 59.02 & 60.45 & 39.33 & 42.16 & 103.52 & 118.71 & 142.85 & 160.87 \\
\hline $\begin{array}{c}\text { T3:Foliar application } \mathrm{ZnSO}_{4} @ 0.5 \% \\
\text { at } 45 \mathrm{DAS}\end{array}$ & 1.16 & 1.25 & 39.79 & 40.25 & 59.92 & 61.54 & 41.50 & 44.03 & 113.07 & 126.12 & 154.57 & 170.16 \\
\hline $\begin{array}{l}\mathrm{T}_{4} \text { : Soil application } \mathrm{Zn} @ 5 \mathrm{~kg} / \mathrm{ha}+ \\
\text { Foliar application of } \mathrm{ZnSO}_{4} @ 0.5 \% \\
\text { at } 45 \text { DAS }\end{array}$ & 1.24 & 1.35 & 42.78 & 43.65 & 61.53 & 63.20 & 50.57 & 52.70 & 127.55 & 133.82 & 178.12 & 186.52 \\
\hline T5:Soil application B @ 1.5 kg/ha & 0.51 & 0.59 & 33.57 & 35.06 & 42.69 & 45.52 & 36.05 & 38.76 & 78.04 & 90.66 & 114.09 & 129.43 \\
\hline $\begin{array}{c}\text { T }_{6}: \text { Foliar application Borax @ } 0.3 \% \\
\text { at } 45 \text { DAS }\end{array}$ & 0.48 & 0.56 & 34.01 & 35.50 & 44.34 & 46.25 & 38.50 & 40.99 & 79.63 & 88.70 & 118.13 & 129.69 \\
\hline $\begin{array}{l}\text { T}_{7} \text { : Soil application B @ } 1.5 \mathrm{~kg} / \mathrm{ha}+ \\
\text { Foliar application Borax @ } 0.3 \% \text { at } \\
45 \text { DAS }\end{array}$ & 0.55 & 0.62 & 35.99 & 37.45 & 44.78 & 46.35 & 43.62 & 46.04 & 89.92 & 97.34 & 133.54 & 143.38 \\
\hline $\begin{array}{c}\mathrm{T}_{8}: \text { Foliar application } \mathrm{ZnSO}_{4} @ 0.5 \% \\
\text { + Borax @ } 0.3 \% \text { at } 45 \text { DAS }\end{array}$ & 1.09 & 1.18 & 43.21 & 44.35 & 62.87 & 64.25 & 56.13 & 59.16 & 133.66 & 144.15 & 189.79 & 203.31 \\
\hline $\begin{array}{c}\text { T9: Soil application Zn @ } 5 \mathrm{~kg} / \mathrm{ha}+\text { B } \\
\text { @ } 1.5 \mathrm{~kg} / \mathrm{ha}\end{array}$ & 1.12 & 1.23 & 41.32 & 42.65 & 60.54 & 62.52 & 44.71 & 47.18 & 118.42 & 131.03 & 163.12 & 178.21 \\
\hline SEm \pm & 0.08 & 0.05 & 1.60 & 2.11 & 1.63 & 1.9 & 2.04 & 2.75 & 4.45 & 7.62 & 5.12 & 8.07 \\
\hline $\mathrm{CD}(\mathrm{P}=0.05)$ & 0.25 & 0.16 & 4.79 & 6.32 & 4.89 & 5.8 & 6.11 & 8.26 & 13.34 & 22.83 & 15.36 & 24.19 \\
\hline CV (\%) & 16.7 & 9.0 & 7.3 & 9.3 & 5.3 & 6.1 & 8.4 & 10.7 & 7.8 & 12.0 & 6.3 & 9.1 \\
\hline
\end{tabular}


Table.3 Boron content and its uptake by linseed as affected by application of $\mathrm{Zn}$ and B

\begin{tabular}{|c|c|c|c|c|c|c|c|c|c|c|c|c|}
\hline \multirow[t]{3}{*}{ Treatments } & \multicolumn{6}{|c|}{ Boron content (mg/kg) } & \multicolumn{6}{|c|}{ Boron uptake (g/ha) } \\
\hline & \multicolumn{2}{|c|}{ Soil } & \multicolumn{2}{|c|}{ Seed } & \multicolumn{2}{|c|}{ Straw } & \multicolumn{2}{|c|}{ Seed } & \multicolumn{2}{|c|}{ Straw } & \multicolumn{2}{|c|}{ Total } \\
\hline & $\begin{array}{c}2018- \\
19\end{array}$ & $\begin{array}{c}2019 \\
-20\end{array}$ & $\begin{array}{c}2018- \\
19\end{array}$ & $\begin{array}{c}2019 \\
-20\end{array}$ & $\begin{array}{c}2018- \\
19\end{array}$ & $\begin{array}{l}2019- \\
20\end{array}$ & $\begin{array}{c}2018 \\
-19\end{array}$ & $\begin{array}{c}2019- \\
20\end{array}$ & $\begin{array}{c}2018- \\
19\end{array}$ & $\begin{array}{c}2019- \\
20\end{array}$ & $\begin{array}{c}2018- \\
19\end{array}$ & $\begin{array}{c}2019 \\
20\end{array}$ \\
\hline $\mathbf{T}_{1}:($ control $)$ & 0.34 & 0.38 & 4.08 & 4.20 & 9.84 & 8.56 & 3.23 & 3.76 & 10.74 & 11.02 & 13.97 & 14.78 \\
\hline T2: Soil application Zn @ 5 Kg/ha & 0.37 & 0.40 & 4.25 & 4.25 & 9.90 & 9.25 & 4.31 & 4.55 & 17.36 & 18.09 & 21.67 & 22.64 \\
\hline $\begin{array}{c}\text { T3:Foliar application } \mathrm{ZnSO}_{4} @ 0.5 \% \\
\text { at } 45 \text { DAS }\end{array}$ & 0.41 & 0.42 & 4.38 & 4.44 & 10.06 & 10.26 & 4.57 & 4.84 & 18.99 & 20.94 & 23.56 & 25.78 \\
\hline $\begin{array}{l}\mathrm{T}_{4} \text { : Soil application } \mathrm{Zn} @ 5 \mathrm{~kg} / \mathrm{ha}+ \\
\text { Foliar application of } \mathrm{ZnSO}_{4} @ 0.5 \% \text { at } \\
45 \text { DAS }\end{array}$ & 0.38 & 0.40 & 4.21 & 4.50 & 9.90 & 10.56 & 4.98 & 5.40 & 20.53 & 22.38 & 25.51 & 27.78 \\
\hline T5:Soil application B @ 1.5 kg/ha & 0.49 & 0.53 & 4.97 & 5.25 & 13.35 & 13.75 & 5.34 & 5.79 & 24.41 & 27.57 & 29.75 & 33.36 \\
\hline $\begin{array}{c}\text { T }_{6}: \text { Foliar application Borax @ } 0.3 \% \text { at } \\
\text { 45 DAS }\end{array}$ & 0.47 & 0.52 & 4.62 & 4.85 & 12.09 & 12.86 & 5.23 & 5.58 & 21.72 & 24.71 & 26.95 & 30.29 \\
\hline $\begin{array}{l}\mathrm{T}_{7} \text { : Soil application B @ } 1.5 \mathrm{~kg} / \mathrm{ha}+ \\
\text { Foliar application Borax @ } 0.3 \% \text { at } 45 \\
\text { DAS }\end{array}$ & 0.51 & 0.55 & 5.23 & 5.56 & 14.43 & 14.42 & 6.34 & 6.85 & 28.98 & 30.26 & 35.32 & 37.11 \\
\hline $\begin{array}{c}\mathrm{T}_{8}: \text { Foliar application } \mathrm{ZnSO}_{4} @ 0.5 \% \\
\text { + Borax @ } 0.3 \% \text { at } 45 \text { DAS }\end{array}$ & 0.44 & 0.48 & 5.48 & 5.58 & 16.67 & 16.52 & 7.12 & 7.42 & 35.45 & 36.99 & 42.57 & 44.41 \\
\hline $\begin{array}{c}\text { T9: }_{9} \text { Soil application Zn @ } 5 \mathrm{~kg} / \mathrm{ha}+\mathrm{B} \\
\text { @ } 1.5 \mathrm{~kg} / \mathrm{ha}\end{array}$ & 0.46 & 0.50 & 4.65 & 4.90 & 13.12 & 13.45 & 5.03 & 5.41 & 25.67 & 28.19 & 30.7 & 33.6 \\
\hline SEm \pm & 0.03 & 0.03 & 0.34 & 0.2 & 0.64 & 0.7 & 0.32 & 0.32 & 1.04 & 2.01 & 1.28 & 1.31 \\
\hline $\mathrm{CD}(\mathrm{P}=\mathbf{0 . 0 5})$ & 0.10 & 0.09 & 1.02 & 0.7 & 1.92 & 2.2 & 0.97 & 0.95 & 3.12 & 6.02 & 3.85 & 3.91 \\
\hline CV (\%) & 13.9 & 11.2 & 12.7 & 8.5 & 9.1 & 10.4 & 11.0 & 10.0 & 8.0 & 14.2 & 8.0 & 7.5 \\
\hline
\end{tabular}


The uptake is affected by yield parameters and therefore, the yield being highest with treatment where foliar application of $\mathrm{ZnSO}_{4}$ @ $0.5 \%$ + foliar application of Borax @ 0.3\% at 45 DAS affected the uptake of zinc. The data in Table 2 revealed that Zinc uptake by seed was found significantly maximum (56.13 $\mathrm{g} / \mathrm{ha}$ and $59.16 \mathrm{~g} / \mathrm{ha}$ ) with the treatment where foliar application of $\mathrm{ZnSO}_{4} @ 0.5 \%$ + foliar application of Borax @ 0.3\% at 45 DAS was given except soil application of Zn@ $5 \mathrm{~kg} / \mathrm{ha}$ + foliar application of $\mathrm{ZnSO}_{4} @ 0.5 \%$ at 45 DAS $(50.57 \mathrm{~g} / \mathrm{ha}$ and $52.70 \mathrm{~g} / \mathrm{ha})$. In case of straw also zinc uptake was found maximum $(133.66 \mathrm{~g} / \mathrm{ha}$ and $144.15 \mathrm{~g} / \mathrm{ha})$ with the treatment foliar application of $\mathrm{ZnSO}_{4} @ 0.5 \%$ + foliar application of Borax @ 0.3\% at 45 DAS in both the years. The increase in nutrient uptake due to zinc and boron application was due to increased requirement consequent to increase yields. These results are supported by the findings of Tahir et al., (2014) and Bakry et al., (2015).

\section{B content and its uptake by linseed as affected by application of $\mathrm{Zn}$ and $\mathrm{B}$}

Data in Table 3 showed that boron content in soil after harvest of the crop was found significantly maximum $(0.51 \mathrm{mg} / \mathrm{kg}$ and 0.55 $\mathrm{mg} / \mathrm{kg}$ ) with the treatment where soil application of B @ $1.5 \mathrm{~kg} / \mathrm{ha}+$ foliar application of Borax @ $0.3 \%$ at 45 DAS over control $(0.34 \mathrm{mg} / \mathrm{kg}$ and $0.38 \mathrm{mg} / \mathrm{kg})$, soil application of Zn @ $5 \mathrm{~kg} / \mathrm{ha}(0.37 \mathrm{mg} / \mathrm{kg}$ and $0.40 \mathrm{mg} / \mathrm{kg}$ ) and soil application of $\mathrm{Zn} @ 5$ $\mathrm{kg} / \mathrm{ha}+$ Foliar application of $\mathrm{ZnSO}_{4} @ 0.5 \%$ at 45 DAS $(0.38 \mathrm{mg} / \mathrm{kg}$ and $0.40 \mathrm{mg} / \mathrm{kg})$ was applied in both the years of experimentation.

Boron content in seed was found significantly maximum $(5.48 \mathrm{mg} / \mathrm{kg}$ and $5.58 \mathrm{mg} / \mathrm{ha})$ with the treatment where foliar application of $\mathrm{ZnSO}_{4} @ 0.5 \%$ + foliar application of Borax @ $0.3 \%$ at 45 DAS was applied but it was at par with soil application of B @ $1.5 \mathrm{~kg} / \mathrm{ha}$
(4.97 $\mathrm{mg} / \mathrm{kg}$ and $5.25 \mathrm{mg} / \mathrm{kg}$ ), foliar application of Borax @ 0.3\% at 45 DAS (4.62 $\mathrm{mg} / \mathrm{ha}$ and $4.85 \mathrm{mg} / \mathrm{ha}$ ), soil application of B @ $1.5 \mathrm{~kg} / \mathrm{ha}+$ foliar application of Borax @ $0.3 \%$ at $45 \mathrm{DAS}(5.23 \mathrm{mg} / \mathrm{ha}$ and $5.56 \mathrm{mg} / \mathrm{ha})$ and soil application of Zn @ $5 \mathrm{~kg} / \mathrm{ha}+\mathrm{B} @$ $1.5 \mathrm{~kg} / \mathrm{ha}$ (4.65 mg/ha and $4.90 \mathrm{mg} / \mathrm{ha}$ ). Treatment with foliar application of $\mathrm{ZnSO}_{4} @$ $0.5 \%$ + foliar application of Borax @ 0.3\% at 45 DAS was found significantly higher boron content in straw over rest of the treatments in both years of experimentation.

Boron uptake by seed was recorded significantly highest (7.12 g/ha and $7.42 \mathrm{~g} / \mathrm{ha})$ with treatment where foliar application of $\mathrm{ZnSO}_{4} @ 0.5 \%$ + foliar application of Borax @ $0.3 \%$ at 45 DAS was applied over rest of the treatments except soil application of B @ $1.5 \mathrm{~kg} / \mathrm{ha}+$ foliar application of Borax @ 0.3\% at 45 DAS (6.34 g/ha and $6.85 \mathrm{~g} / \mathrm{ha})$. Boron uptake by straw was also found significantly maximum (35.45 g/ha and $36.99 \mathrm{~g} / \mathrm{ha})$ with the treatment foliar application of $\mathrm{ZnSO}_{4}$ @ $0.5 \%$ + foliar application of Borax @ 0.3\% at 45 DAS over rest of the treatments in both the years. The increase in boron uptake by seed and straw may be due to maximum seed yield and straw yield which ultimately accumulated more boron. The results of this investigation are in consonance with the findings of Raghav et al., (2016).

Based on the findings of two years of experimentation it may be concluded that foliar application of $\mathrm{ZnSO}_{4} @ 0.5 \%$ along with foliar application of Borax @ 0.3\% at 45 DAS was found most effective for yield and beneficial in uptake of $\mathrm{Zn}$ and $\mathrm{B}$ nutrition by linseed.

\section{Acknowledgement}

Author is very thankful to AICRIP(Linseed), Directorate of Oilseeds Research, Hyderabad for financial support. 


\section{References}

Bakry, B. A., Nofal, O. A., Zeidan, M. S. and Hozayn, M. 2015. Potassium and zinc in relation to improve flax varieties yield and yield components as grown under sandy soil conditions. Agricultural Sciences, 6 (01): 152.

Bhagwat, G. J., Gokhale, D. N., Waghmare, P. K. and Bhalerao, A. 2018. Effect of micronutrient application on quality and economics of soybean. Int. J. Curr. Microbiol. App. Sci. 6: 18601865.

Gomez, K. A. and Gomez, A. A. 1984. Statistical Procedures for Agricultural Research. John Wiley \& Sons.

Kumar, V., Singh, S.K. and Suman, S.N. 2014. Zinc-Boron interaction effects on yield, nutrient uptake and quality of mustard (Brassica juncea L.) in ustifluvents. RAU Journal of Research. 24 (1\&2): 59-63.

Maharnor, R. Y., Indulkar, B. S., Lokhande, P. B., Jadhav, L. S., Padghan, A. D. and Sonune, P. N. 2018. Effect of different levels of zinc on yield and quality of groundnut (Arachis hypogea L.) in Inceptisol. Int. J. Curr. Microbiol App
Sci. 6: 2843-2848.

Marchenkov, A., Rozhmina, T. Uschapovsky, I. and Muir, A. D. 2003. Cultivation of flax. In A. D. Muir and N. D. Westcott (eds). Flax - The genus Linum. Taylor and Francis, London.

Mishra, U. S. and Dhakar, R. 2016. Response of linseed (Linum usitatissimum) to sulphur and boron application under rainfed condition. New Agriculturist, 27(1): 181-184.

P. C. Report, 2018-19, AICRP on Linseed.

Raghav, D. K., Singh, R. K. and Saha, P. B. 2016. Effect of sulphur and boron application on uptake and yield of linseed under rainfed conditions. The Ecosan, Special issue, Vol. IX: 737741.

Singh, A., Singh, D., Verma, V. K., Pyare, R. and Hussain, M. F. 2020. Studies on the effect of zinc and boron on growth and yield of linseed (Linum usitatissimum L.) under limited irrigation. International Journal of Chemical Studies. 8(5): 1964-1966.

Tahir, M., Irfan, M. and Rehman, A.U. 2014. Effect of foliar application of zinc on yield and oil contents of flax. Pakistan J. Agric. Res., 27(4): 287-295.

\section{How to cite this article:}

Md. Parwaiz Alam, Kumari Menka, Sulochna, Md. Naiyar. Ali and Lakra, R. K. 2020. Effect of Zinc and Boron on Uptake, Yield and Quality of Linseed (Linum usitatissimum L.). Int.J.Curr.Microbiol.App.Sci. 9(12): 3512-3519. doi: https://doi.org/10.20546/ijcmas.2020.912.417 